\title{
ANALISIS KINERJA KEUANGAN BERBASIS RASIO PADA PERUSAHAAN BACHRI DARMO KOTA MALANG (STUDI KASUS PERUSAHAAN BACHRI DARMO KOTA MALANG/AREA MALANG)
}

\author{
Elly Lestari ${ }^{1}$ Maria Guadalupe Ngono ${ }^{2}$ \\ ${ }^{1)}$ Staf Pengajar Program Studi Manajemen Fakultas Ekonomi Universitas Tribhuwana Tunggadewi \\ ${ }^{2)}$ Mahasiswa Program Studi Manajemen Fakultas Ekonomi Universitas Tribhuwana Tunggadewi
}

\begin{abstract}
ABSTRAK
Kinerja keuangan merupakan gambaran umum prestasi yang dicapai perusahaan Bachri Darmo dalam kegiatan operasionalnya baik menyangkut aspek kuangan, pemasaran, penghimpunan dana dan penyaluran dana. Tindakan untuk mengetahui kinerja keuangan diketahui dari berbagai perhitungan rasio seperti likuiditas, profitabilitas dan aktiva. Tujuan untuk mengetahui kinerja Keuangan pada perusahaan tersebut melalui analisis rasio likuiditas, rasio profitabilitas dan rasio aktiva.

Penelitian yang dilakukan merupakan penelitian dengan mengunakan metode deskriptif kuantitatif. Data penelitian menggunakan laporan keuangan Perusahaan Bachri Darmo Kota Malang periode 2014-2016. Teknik pengumpulan data yang digunakan oleh peneliti adalah dokumentasi. Metode analisa data yang di gunakan adalah deskriptif dan rasio keuangan.

Hasil penelitian membuktikan bahwa kinerja keuangan perusahaan Bachri Darmo Kota Malang dalam keadaan baik karena nilai likuiditas perusahaan berdasarkan current ratio cukup tinggi untuk membayar utang, nilai Return On Assets (ROA) cukup tinggi, Rasio Lancar (Current Ratio) cukup tinggi dan nilai Asset Trun Over (ATO) tinggi. Perusahaan diharapkan menjaga kinerja keuangan yang baik sehingga mampu mengetahui kesehatan usaha yang bertujuan untuk pengambilan keputusan.
\end{abstract}

Kata Kunci: Kinerja Keuangan, Rasio Aktiva, Rasio Likuiditas Dan Rasio Profitabilitas.

\section{PENDAHULUAN}

Zaman sekarang ini merupakan era persaingan ketat antar perusahaan. Setiap perusahaan harus menggambarkan keunggulan kompotitifnya agar dapat bertahan dan memajukan perusahaannya. Salah satunya keunggulan yang perlu dikembangkan oleh perusahaan adalah kinerja keuangan perusahan. Salah satu komponen yang sangat penting bagi kinerja perusahaan adalah manajemen laba (kerja keuangan). Hal ini karena manajemen laba (kerja keuangan) berpengaruh secara langsung pada likuiditas dan profitabilitas perusahaan.
Setiap perusahaan dalam menjalankan aktivitasnya memerlukan suatu informasi mengenai kondisi perusahaan yang terjadi dari tahun ke tahun. Salah satu cara untuk mengetahui apakah perusahaan dalam menjalankan aktivitasnya telah sesuai dengan rencana atau tidak. Tujuan perusahaan adalah dengan mengukur kinerja keuangan. Pengukuran kinerja perusahaan dapat dipergunakan untuk menilai keberhasilan perusahaan dan juga dapat digunakan sebagai dasar untuk menyusun strategi perusahaan.

Pengukuran kinerja perusahaan dilakukan oleh manajemen atau manajer keuangan. Pengukuran kinerja tersebut dilakukan dengan 
tujuan untuk menemukan kelemahan didalam kinerja keuangan perusahaan yang dapat menyebabkan masalah dimasa yang akan datang dan untuk menentukan kekuatan perusahaan yang dapat diandalkan. Pengukuran kinerja juga dapat digunakan sebagai bahan pertimbangan dalam mengambil keputusan dimasa yang akan datang.

Salah satu dasar yang dapat dijadikan sebagai acuan dalam mengukur kinerja perusahaan adalah laporan keuangan. Laporan keuangan merupakan salah satu sumber informasi yang penting bagi perusahaan (Indriyo, 2012). Laporan keuangan terdiri dari neraca, laporan laba rugi, laporan arus kas, dan laporan pendukung seperti laporan laba ditahan, dan perubahan modal sendiri.

Rasio keuangan adalah salah satu angka yang dibandingkan dengan angka lain untuk menilai kinerja suatu perusahaan berdasarkan perbandingan data keuangan yang terdapat pada pos laporan keuangan (neraca, laporan laba/rugi, laporan aliran kas). Salah satu cara pemrosesan dan penginterpretasian informasi akuntansi, yang dinyatakan dalam artian relatif maupun absolut untuk menjelaskan hubungan tertentu antara angka yang satu dengan angka yang laindari suatu laporan keuangan.

Perusahaan secara periodik selalu mengeluarkan laporan keuangan yang dibuat oleh bagian accounting dan diberikan kepada pihak-pihak yang berkepentingan, misalnya pemerintah, kreditor, pemilik perusahaan dan pihak manajemen sendiri.

Laporan keuangan merupakan catatan tentang informasi keuangan perusahaan pada suatu waktu akutansi, yang dipakai untuk menggambarkan kondisi atau kinerja perusahaan tersebut. Laporan keuangan umumnya disajikan untuk memberi informasi mengenai posisi-posisi keuangan, kinerja dan arus kas suatu perusahaan dalam periode tertentu. Informasi tersebut diharapkan dapat bermanfaat bagi sebagian besar kalangan pengguna laporan keuangan dalam rangka membuat keputusan-keputusan. Penilaian tingkat keuangan suatu perusahaan dapat dilakukan dengan menganalisis laporan keuangan perusahaan. Untuk mengetahui apakah laporan keuangan perusahaan dalam kondisi yang baik dan dapat dilakukan berbagai analisa, salah satunya adalah analisis rasio. Analisis rasio keuangan, membantu mengetahui tingkat kinerja keuangan perusahaan apakah baik atau sebaliknya (Kasmir, 2012).

Analisis rasio dapat diklasifikasikan beberapa bagian rasio likuiditas, aktivitas dan profitabilitas. Tingkat likuiditas adalah menunjukan sejauh mana kemampuan perusahaan dalam memenuhi kewajiban jangka pendeknya dengan jaminan harta lancar yang dimilikinya. Tingkat aktivitas, mengukur efektivitas suatu perusahaan dalam menggunakan aktiva yang dimilikinya. Tingkat perolehan laba menunjukkan sejauh 
mana kemampuan perusahaan dalam menghasilkan laba dengan modal yang dimilikinya. Apakah perusahaan-perusahaan yang kelihatan besar sudah bisa menyatakan keefektifan kinerja perusahaan tersebut. Beberapa penelitian mengenai manajemen laba, rasio-rasio keuangan. Oleh sebab itu dalam penelitian ini, rasio-rasio keuangan terhadap perum pegadaian. Penelitian mengenai, rasio-rasio keuangan ini bertujuan untuk memberikan bukti empiris bahwa salah satu penentuan kinerja keuangan, dengan anggapan bahwa kinerja keuangan yang dilihat dari laporan keuangan lebih menggambarkan kondisi perusahaan.

Penelitian ini untuk mengetahui kinerja Keuangan pada Perusahaan melalui analisis rasio likuiditas, rasio profitabilitas dan rasio aktiva.

\section{TINJAUAN PUSTAKA}

Rasio Keuangan adalah alat analisis keuangan perusahaan untuk menilai kinerja suatu perusahaan berdasarkan perbandingan data keuangan apakah memperoleh laba dari modal yang diberikan perushaan dalam transaksi jual beli. Profitabilitas diartikan sebagai kemampuan perusahaan memperoleh laba dari penjualan, total aktiva maupun modal sendiri. Rasio likuiditas menggambarkan kemampuan suatu perusahaan dalam memenuhi kewajibanya. Rasio aktiva mengukur seberapa efektif perusahaan menggunakan sumber daya yang dimilikinya.

\section{METODE PENELITIAN}

Penelitian yang dilakukan merupakan penelitian dengan mengunakan metode deskriptif kuantitatif. Data penelitian menggunakan laporan keuangan Perusahaan Bachri Darmo Kota Malang periode 20142016. Teknik pengumpulan data yang digunakan oleh peneliti adalah dokumentasi. Metode analisa data yang di gunakan adalah deskriptif dan rasio keuangan.

\section{HASIL DAN PEMBAHASAN}

\section{Rasio Likuiditas}

Pengukurannya menggunakan rumus rasio lancar (current ratio) sebagai berikut:

Tabel 1: Kinerja Keuangan Berdasarkan Rasio Lancar (Current Ratio) Pada Perusahaan Bachri Darmo Kota Malang

\begin{tabular}{|c|c|c|c|c|}
\hline Tahun & Aset/Aktiva & & Hutang & Current ratio \\
\hline 2014 & $\mathrm{Rp} \quad 782.310 .000$ & $\mathrm{Rp}$ & 36.000 .000 & $21,73 \%$ \\
\hline 2015 & Rp $\quad 808.710 .000$ & $\mathrm{Rp}$ & 42.000 .000 & $19,26 \%$ \\
\hline 2016 & Rp $\quad 853.390 .000$ & $\mathrm{Rp}$ & 30.000 .000 & $28,45 \%$ \\
\hline
\end{tabular}

Sumber : Diolah, 2018

Pengukuran kinerja keuangan

berdasarkan rasio lancar (current ratio) pada perusahaan Bachri Darmo Kota Malang dinyatakan kinerja keuangan dalam keadaan baik karena nilai current ratio cukup tinggi, didapatkan tahun 2014 sebanyak 21,73\%, tahun 2015 sebanyak 19,26\% dan tahun 2016 sebanyak 28,45\%, hal ini membuktikan 
bahwa perusahaan mengalami kemampuan yang cukup tinggi untuk membayar utang atau memenuhi kebutuhan jangka pendek yang harus dipenuhi.

\section{Rasio Profitabilitas}

Rasio profitabilitas diukur berdasarkan Return On Assets (ROA) pada Perusahaan Bachri Darmo Kota Malang, sebagai berikut:

Tabel 2: Kinerja Keuangan Berdasarkan Return On Assets (ROA) pada Perusahaan Bachri Darmo Kota Malang

\begin{tabular}{|c|c|c|c|}
\hline Tahun & Laba Usaha & Aset & $\mathrm{ROA}$ \\
\hline 2014 & 78.170 .000 & Rp 782.310.000 & $9,99 \%$ \\
\hline 2015 & $\operatorname{Rp} \quad 101.395 .000$ & $\operatorname{Rp} 808.710 .000$ & $12,54 \%$ \\
\hline 2016 & 96.630 .000 & $\operatorname{Rp} 853.390 .000$ & $11,32 \%$ \\
\hline
\end{tabular}

Sumber : Diolah, 2018

Pengukuran kinerja keuangan berdasarkan Return On Assets (ROA) pada perusahaan Bachri Darmo Kota Malang dinyatakan kinerja keuangan dalam keadaan baik karena nilai ROA cukup tinggi, didapatkan tahun 2014 sebanyak 9,99\%, tahun 2015 sebanyak 12,54\% dan tahun 2016 sebanyak 11,32\%, hal ini membuktikan bahwa perusahaan mengalami keuntungan yang cukup tinggi.

Rasio profitabilitas diukur berdasarkan Retun on Equity (ROE) Pada Perusahaan Bachri Darmo Kota Malang, sebagai berikut:

Tabel 3: Kinerja Keuangan Berdasarkan Retun on Equity (ROE) Pada Perusahaan Bachri Darmo Kota Malang

\begin{tabular}{|c|c|c|c|}
\hline Tahun & Laba Usaha & Modal usaha & ROE \\
\hline 2014 & 78.170 .000 & Rp 511.700 .000 & $15,28 \%$ \\
\hline 2015 & Rp 101.395 .000 & Rp 530.600 .000 & $19,11 \%$ \\
\hline 2016 & 96.630 .000 & Rp 560.520 .000 & $17,24 \%$ \\
\hline
\end{tabular}

Sumber : Diolah, 2018

Pengukuran kinerja keuangan berdasarkan Retun on Equity (ROE) pada perusahaan Bachri Darmo Kota Malang dinyatakan kinerja keuangan dalam keadaan baik karena nilai ROE cukup tinggi, didapatkan tahun 2014 sebanyak 15,28\%, tahun 2015 sebanyak 19,11\% dan tahun 2016 sebanyak 17,24\%, hal ini membuktikan bahwa perusahaan mengalami keuntungan yang cukup tinggi.

\section{Rasio Aktiva}

Pengukurannya menggunakan rumus Asset Trun Over (ATO) sebagai berikut:

Tabel 4: Kinerja Keuangan Berdasarkan Asset Trun Over (ATO) Pada Perusahaan Bachri Darmo Kota Malang

\begin{tabular}{|c|c|c|c|}
\hline Tahun & Penjualan & Aktiva & ATO \\
\hline 2014 & $\begin{array}{ll}\mathrm{Rp} & 860.480 .000\end{array}$ & Rp 782.310.000 & $109,99 \%$ \\
\hline 2015 & $\mathrm{Rp} \quad 910.105 .000$ & Rp 808.710.000 & $112,54 \%$ \\
\hline 2016 & $\begin{array}{ll}\mathrm{Rp} & 950.020 .000 \\
\end{array}$ & Rp 853.390.000 & $111,32 \%$ \\
\hline
\end{tabular}

Sumber : Diolah, 2018 
Pengukuran kinerja keuangan berdasarkan Asset Trun Over (ATO) pada perusahaan Bachri Darmo Kota Malang dinyatakan kinerja keuangan dalam keadaan baik karena nilai ATO tinggi, didapatkan tahun 2014 sebanyak 109,99\%, tahun 2015 sebanyak 112,54\% dan tahun 2016 sebanyak $111,32 \%$. Hal ini membuktikan bahwa perusahaan mengalami perputaran aktiva yang sangat cepat dan tinggi sehingga perusahaan dinyatakan dalam keadaan berkembang dan mengalami peningkatan penjualan yang tinggi.

\section{PEMBAHASAN}

Berdasarkan hasil analisis didapatkan bahwa kinerja keuangan perusahaan Bachri Darmo Kota Malang dalam keadaan baik karena nilai likuiditas perusahaan berdasarkan current ratio cukup tinggi untuk membayar utang pada tahun 2014 sebanyak 21,73\%, tahun 2015 sebanyak 19,26\% dan tahun 2016 sebanyak 28,45\%, kinerja keuangan berdasarkan nilai Return On Assets (ROA) cukup tinggi dari tahun 2014 sebanyak 9,99\%, tahun 2015 sebanyak 12,54\% dan tahun 2016 sebanyak 11,32\%, kinerja keuangan berdasarkan Rasio Lancar (Current Ratio) cukup tinggi dari tahun 2014 sebanyak 15,28\%, tahun 2015 sebanyak 19,11\% dan tahun 2016 sebanyak 17,24\%. Sedangkan kinerja keuangan berdasarkan Asset Trun Over (ATO) tinggi dari tahun 2014 sebanyak 109,99\%, tahun 2015 sebanyak 112,54\% dan tahun 2016 sebanyak 111,32\%.
Kinerja keuangan perusahaan Bachri Darmo Kota Malang berdasarkan rasio likuiditas menggunakan Current Ratio dinyatakan cukup tinggi, dikarenakan perusahaan mampu memenuhi atau membayar utang jangka pendek tepat waktu. Tujuan pengelolaan likuiditas untuk menurunkan serendah mungkin biaya dana, hal ini dapat dilakukan dengan cara memilih komposisi sumber dana yang akan memberikan biaya yang paling rendah. Perhitungan rasio likuiditas untuk mengatahui peningkatan volume kegiatan perusahaan untuk membiayai hutang lancar. Menurut Kasmir (2012), manfaat rasio likuiditas yaitu, untuk mengukur kemampuan perusahaan membayar kewajiban atau utang yang segera jatuh tempo pada saat ditagih, untuk mengukur kemampuan perusahaan membayar kewajiban jangka pendek dengan aktiva lancar secara keseluruhan, tanpa memperhitungkan sediaan atau piutang, untuk membandingkan antara jumlah sediaan yang ada dengan modal kerja perusahaan dan mengukur seberapa besar uang kas yang tersedia untuk membayar utang.

Kinerja keuangan perusahaan Bachri Darmo Kota Malang berdasarkan rasio profitabilitas melalui Return On Assets (ROA) dinyatakan cukup tinggi karena jumlah aset yang digunakan mampu meningkatkan laba usaha yang cukup tinggi setiap tahunnya. Rasio profitabilitas menunjukan keberhasilan perusahaan Bachri Darmo didalam menghasilkan keberuntungan. Dalam hal ini 
dinyatakan tinggkat profit perusahaan dinyatakan cukup tinggi. Berdasarkan Return On Assets (ROA) menunjukkan bahwa perusahaan memiliki kemampuan menghasilkan laba dari aktiva yang digunakan cukup tinggi.

Kinerja keuangan perusahaan Bachri Darmo berdasarkan Retun on Equity (ROE) dinyatakan cukup tinggi sehingga perusahaan mengalami kinerja keuangan baik atau sehat. Kinerja keuangan perusahaan bertujuan untuk memperoleh gambaran yang jelas mengenai keadaan keuangan dan informasi kesehatan perusahaan sebagai acuan dalam pengambilan keputusan, kinerja keuangan yang baik akan mudah dalam menentukan keputusan pengembangan perusahaan. Tindakan peningkatan laba didukung oleh adanya kegiatan manajemen perusahaan sebagai suatu kemampuan untuk menentukan strategi kerja sehingga perusahaan bisa mengambil keputusan yang tepat untuk menjalankan operasional perusahaan (Syamsudin, 2007).

Pengukuran kinerja keuangan berdasarkan profitabilitas merupakan salah satu indikator penting dalam mengukur keberhasilan kerja suatu perusahaan. Kegiatan perusahaan berorientasi untuk mencari keuntungan atau laba yang optimal sehingga diperlukan perencanaan dan pengendalian dalam setiap aktivitas usahanya agar perusahaan dapat membiayai seluruh kegiatan yang berlangsung secara terus menerus.

Kinerja keuangan perusahaan Bachri Darmo Kota Malang berdasarkan Asset Trun
Over (ATO) dinyatakan tinggi, dikarenakan tingkat perputaran aktiva yang sangat cepat dalam memutar aktivitas kerja perusahaan. Rasio aktiva yang mengalami kenaikan dikarenakan faktor aktivitas dinyatakan maksimal sehingga penjualan dan jumlah aktiva lancar yang dimiliki mengalami keseimbangan dan peningkatan, untuk meningkatkan aktivitas maka perlu mengatur strategi aktivitas perusahaan.

Kinerja keuangan sebagai gambaran prestasi yang dicapai perusahaan Bachri Darmo dalam kegiatan operasionalnya baik menyangkut aspek kuangan, aspek pemasaran, aspek penghimpunan dana dan penyaluran dana, aspek teknologi, maupun aspek sumber daya manusianya. Kinerja mencerminkan kemampuan perusahaan Bachri Darmo dalam mengelola dan mengalokasikan sumber dayanya maka kinerja menjadi hal penting yang harus dicapai. Penilaian kondisi keuangan dan perkembangan perusahaan dapat dilihat dalam laporan keuangan yang berguna bagi perencanaan dan pengambilan keputusan jangka pendek maupun jangka panjang serta merupakan persoalan yang kompleks dan sulit karena menyangkut masalah efektifitas dan pemanfaatan modal, efisiensi dari kegiatan perusahaan. Proses penilaian laporan keuangan menggunakan rasio keuangan untuk mengetahui perkembangan atau penurunan kondisi ekonomi perusahaan.

Hasil penelitian ini didukung oleh penelitian Sari (2007), membuktikan bahwa 
kinerja keuangan perusahaan mempengaruhi operasional dan penentuan pengambilan keputusan sehingga perusahaan mampu bersaing dengan perusahaan lain. Berdasarkan hasil penelitian maka diketahui bahwa kinerja keuangan yang baik mampu mengontrol perusahaan dalam mengembangkan usaha sehingga menumbuhkan perkembangan perusahaan.

\section{KESIMPULAN}

Berdasarkan hasil analisis dapat disimpulkan bahwa:

1. Kinerja keuangan perusahaan Bachri Darmo Kota Malang berdasarkan rasio likuiditas dinyatakan baik dengan nilai current ratio cukup tinggi, hal tersebut dikarenakan perusahaan mampu memenuhi atau membayar utang jangka pendek tepat waktu. Perhitungan rasio likuiditas untuk mengatahui peningkatan volume kegiatan perusahaan untuk membiayai hutang lancar.

2. Kinerja keuangan perusahaan Bachri Darmo Kota Malang berdasarkan rasio profitabilitas dinyatakan baik dengan nilai Return On Assets (ROA) dan Retun on Equity (ROE) cukup tinggi karena jumlah aset yang digunakan mampu meningkatkan laba usaha yang cukup tinggi setiap tahunnya. Rasio profitabilitas menunjukan keberhasilan perusahaan Bachri Darmo didalam menghasilkan keberuntungan, dalam hal ini dinyatakan tinggkat profit perusahaan dinyatakan cukup tinggi.
Berdasarkan hasil penelitian menunjukkan bahwa perusahaan memiliki kemampuan menghasilkan laba dari aktiva yang digunakan cukup tinggi.

3. Kinerja keuangan perusahaan Bachri Darmo Kota Malang berdasarkan rasio aktiva dinyatakan baik karena nilai Asset Trun Over (ATO) dinyatakan tinggi, dikarenakan tingkat perputaran aktiva yang sangat cepat dalam memutar aktivitas kerja perusahaan. Rasio aktiva yang mengalami kenaikan karena aktivitas operasional perusahaan maksimal untuk meningkatkan penjualan sehingga meningkatkan pendapatan dan keuntungan.

\section{DAFTAR PUSTAKA}

Kasmir. 2012. Analisis Laporan Keuangan. Jakarta: Raja Grafindo Persada.

Sari, Maylina. 2007. Kemampuan Rasio Keuangan sebagai Alat untuk Memprediksi Peringkat Obligasi (PT Pefindo). Jurnal Bisnis dan Ekonomi (JBE), Semarang. http://www.unisbank.ac.id/ojs/index.php/fe 3/article/viewFile/243/179. Diunduh 31 Maret 2018 pukul 13:45 WIB.

Sawir, Agnes. 2009. Analisa Kinerja Keuangan dan Perencanaan keauangan Perusahaan. Jakarta: Gramedia Pustaka Utama.

Sukirno, S. 2014. Ekonomi Pembangunan : Proses, Masalah Dan Kebijakan.Jakarta: Kencana.

Syamsudin, L. 2007. Manajemen Keuangan Perusahaan. Yogyakarta: Hanindita. 